\title{
Pharmacobotanical study of Manilkara zapota (L.) P.Royen (Sapotaceae)
}

\author{
Bruna Izabela de Vasconcelos Moura1, Bárbara Priscylla Lira de Araújo1, Rafaela Damasceno Sá1, \\ Karina Perrelli Randau ${ }^{\circledR}$,*
}

\begin{abstract}
${ }^{1}$ Pharmacognosy Laboratory, Department of Pharmaceutical Sciences, Federal University of Pernambuco, Recife, Pernambuco, Brazil
\end{abstract}

\begin{abstract}
Manilkara zapota (L.) P. Royen, popularly known as sapoti or sapota (sapodilla), is a tree bearing an important fruit, in addition to different parts of the plant being widely used in folk medicine in the management of inflammation, pain, fevers, coughs, diarrhea, dysentery, among other ailments. This study aimed to conduct a pharmacobotany standardization study of M. zapota. Semi-permanent slides, containing transversal sections of stem, petiole, leaf blade and fruit; and paradermic sections of leaf blade were prepared, and analyzed by light microscopy. Histochemical tests were also performed in crosssections of the leaf blade. Microscopic analysis allowed the identification of important elements in the diagnosis of the species; while the use of histochemical techniques on the leaf blade showed evidence of the presence of phenolic compounds, tannins, triterpenes and steroids, lipophilic compounds, starch, lignin and calcium oxalate crystals. The results presented contributed to characterization of the species.
\end{abstract}

Keywords: Anatomy. Histochemistry. Sapota. Sapoti. Manilkara/drug effects. Sapotaceae/drug effects.

\section{INTRODUCTION}

The Sapotaceae family contains 58 genera and approximately 1250 species that occur in neotropical regions of the world (Pennington, 1991; Govaerts, Frodin, Pennington, 2001; APG IV, 2016). In Brazil, 233 species are registered, grouped into 12 genera, which can be found in the Amazon, Atlantic Forest, Caatinga, Cerrado, Pampas and Pantanal (Alves Araújo, Alves, 2013; Flora do Brasil 2020, 2017).

Manilkara zapota (L.) P.Royen, native to Mexico and Central America, is the most known fruit tree species of Sapotaceae (Silva Jr. et al., 2014). At present, it is distributed in pantropical regions and is cultivated for its fruit, timber and latex (Lorenzi, Lacerda, Bacher, 2015; Milind, Preeti, 2015). Its common English name is sapodilla (Lim, 2013), while in Brazil it is popularly known as sapoti or sapota, depending on the format in which its fruits are presented (Miranda et al., 2002).

\footnotetext{
*Correspondence: Karina Perrelli Randau. Laboratório de Farmacognosia, Departamento de Ciências Farmacêuticas, Universidade Federal de Pernambuco. Av. Prof. Arthur de Sá, S/N, CDU, CEP 50740-521, Recife, Pernambuco, Brazil. E-mail:krandau@hotmail.com
}

Various parts of the plant are used in folk medicine in the management of inflammation, pain, fevers, coughs, diarrhea, dysentery, because they present diuretic and tonic properties and prevent formation of kidney and bladder stones; in addition to the fruit being useful due to its high nutritional content (Lim, 2013; Milind, Preeti, 2015).

Scientific studies have demonstrated analgesic (Manirujjaman et al., 2014); anti-arthritic (Singh et al., 2011); antidiarrhoeal (Manirujjaman et al., 2013); antiinflammatory and anti-pyretic (Hossain et al., 2012; Ganguly et al., 2013); antimicrobial (Islam et al., 2013; Priya et al., 2014); antioxidant (Kaneria, Chanda, 2012; Fayek et al., 2012; Priya et al., 2014); antitumor (Khalek et al., 2015); hypoglycemic and hypocholesterolemic effects (Fayek et al., 2012; Paul, Hakim, 2015).

The species also presents a diversity of chemical compounds, such as phenolic compounds, terpenes, steroids, saponins, fixed oils, hydrocarbons, carbohydrates, amino acids, minerals and vitamins (Ahmed, Ifzal, Zaidi, 1982; Selvaraj, Pal, 1984; Carvalho Filho et al., 2012; Fayek et al., 2012).

However, there are few studies related to anatomical aspects and to the histolocalization of metabolites in the plant, which could be used as diagnostic features 
for the species. Therefore, this study aimed to perform an anatomical and histochemical characterization of $M$. zapota.

\section{MATERIAL AND METHODS}

The material studied was collected at a site in Jaguarana, located in Paulista in the state of Pernambuco, Brazil. The voucher specimen was deposited in the Herbarium Dárdano de Andrade Lima, of the Instituto Agronômico de Pernambuco (IPA), under registration number 90.643 .

The anatomical study was performed using stems and leaves obtained between the third and fifth nodes, and mature fruits obtained at the crown periphery. The samples were fixed in FAA $_{50}$ (Johansen, 1940). Various crosssections were obtained by hand, using a common razor blade, in the middle region of the stem, petiole, leaf blade and fruit. For the leaf blade, paradermal sections were also performed on the adaxial and abaxial surfaces. All sections were clarified in $50 \%$ sodium hypochlorite solution (Kraus, Arduin, 1997). Semi-permanent histological slides were prepared containing the cross-sections, stained with safranin and Astra blue (Bukatsch, 1972), and the paradermal sections, stained with $1 \%$ methylene blue (Krauter, 1985), following usual plant anatomy procedures (Johansen, 1940; Sass, 1951).

Histochemical tests were made on cross-sections of fresh leaf blades obtained by the same method as that used in the anatomical study (Johansen, 1940). The specific reagents used were: $10 \%$ potassium dichromate for phenolic compounds (Gabe, 1968), vanillin hydrochloric acid for tannins (Mace, Howell, 1974), antimony trichloride for triterpenes and steroids (Mace, Bell, Stipanovic, 1974), Sudan III for lipophilic substances (Sass, 1951), Lugol's iodine reagent for starch (Johansen, 1940), phloroglucinol for lignin (Johansen, 1940) and 10\% hydrochloric acid to establish the nature of the crystals (Jensen, 1962). Cross-sections without any treatment were used as analytical white control.

The semi-permanent histological slides prepared for anatomical and histochemical characterization were analyzed in images captured by digital camera coupled to a light microscope (Alltion), by using a software program (Toup View Image).

\section{RESULTS}

The stem, in cross-section, presented a uniseriate epidermis covered with thick cuticle and lenticels in primary growth (Figures 1A and B). In secondary growth, the development of periderm was observed (Figure 1C).

The cortical region was composed of three to five layers of angular collenchyma, and approximately ten layers of parenchyma (Figures $1 \mathrm{~A}$ and B), whereas, in secondary growth, the cortical region of the stem was formed of parenchyma only (Figure 1C).

In the cortical region of the stem, in both primary and secondary growth, laticifers, lignified cells and prismatic crystals (Figures 1A and C) were found. In the pith of the stem, in both primary and secondary growth, only laticifers and starch grains occurred (Figures 1E and F). Starch grains were also visualized in the endodermis (Figure 1D).

The vascular system of the stem in primary and secondary growth was collateral. Sclerenchyma fibers were located externally to the bundles and between the layers of phloem (Figures 1A and D).

The petiole, in cross-section, had concave-convex shape, with two more prominent regions on the adaxial surface (Figures $2 \mathrm{~A}$ and $\mathrm{B}$ ). The epidermis was composed of a single layer of cells and covered with a thick cuticle (Figures 2A and B). The angular collenchyma was composed of three to six layers of cells and was also present in the ribs on the adaxial surface (Figures 2A and $\mathrm{B})$. The most internal layers were formed of parenchyma (Figures 2A and B).

In the cortical region of the petiole, there was presence of isolated sclereids and groups of fibers (Figure 2A), as well as laticifers, lignified cells, prismatic crystals and starch grains (Figures 2B and C). In the medullary region, laticifers and a nucleus of phloem were found, accompanied by lignified cells (Figure 2D).

A collateral vascular bundle of concave-convex conformation was found in the central region of the petiole (Figure 2D). Sclerenchymatic fibers surrounded the vascular bundle and were also located in the ribs (Figures 2A and D).

In front view, the leaf blade showed epidermal cells with a strongly sinuous contour on the adaxial side (Figure 3A) and cells that had straight or slightly sinuous walls on the adaxial surface (Figure 3B). The leaf blade was hypostomatic (Figures $3 \mathrm{~A}$ and $\mathrm{B}$ ) and had anomocytic stomata on the abaxial surface, located on the same level as the epidermal cells (Figure 3B).

In cross-section, the leaf blade had uniseriate epidermis coated with a thick cuticle (Figure 4A). There were unicellular 2-armed trichomes on both sides of the leaf blade (Figure 4C).

The midrib had concave-convex shape (Figures 4A and B). The angular collenchyma was arranged in three to six layers of cells, being more developed in the abaxial region (Figures $4 \mathrm{~B}$ and $\mathrm{C}$ ). The ground parenchyma 

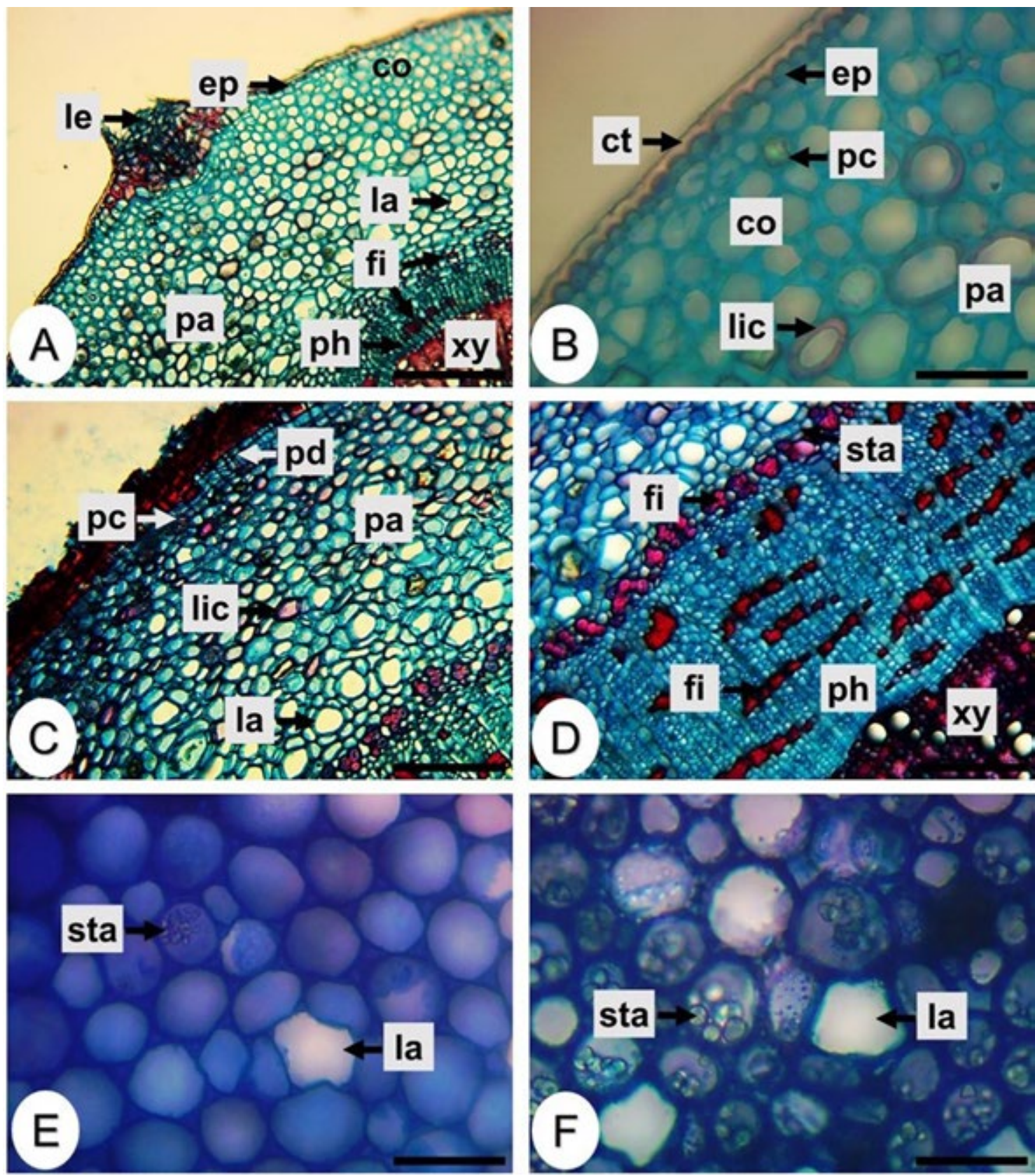

FIGURE 1 - Cross-sections of the stem of Manilkara zapota (L.) P.Royen (Sapotaceae). A, B, E: primary growth. C, D, F: secondary growth Abbreviations: $c o=$ collenchyma; $c t=$ cuticle; $\mathrm{ep}=$ epidermis; $\mathrm{f}=$ fiber; la = laticifer; le = lenticel; lic $=$ lignified cell; $\mathrm{pa}=$ parenchyma; $\mathrm{pc}=$ prismatic crystal; $\mathrm{pd}=$ periderm; $\mathrm{ph}=$ phloem; $\mathrm{sta}=$ starch; $\mathrm{xy}=\mathrm{xylem}$. Bars: $\mathrm{A}, \mathrm{D}, \mathrm{E}=200 \mu \mathrm{m} ; \mathrm{B}, \mathrm{C}, \mathrm{F}=50 \mu \mathrm{m}$.

occupied the central region of the midrib, interrupted by sclerenchymatic fibers that surrounded the vascular system (Figures 4A and B). The vascular system was disposed in the same way as that observed in the petiole (Figures 4A and B). Also similar to that found in the petiole, there was the presence of laticifers, lignified cells, prismatic crystals and starch grains in the cortical region (Figures 4A and B). However, starch grains were also found in the medullary region, in addition to laticifers and a nucleus of phloem accompanied by lignified cells (Figures 4A, B and E).
Stone cells were visualized next to the vascular system (Figures 4A and F).

On the adaxial surface of the leaf blade, a subepidermal layer composed of large and rounded cells was found (Figure 4G). The mesophyll was dorsiventral, presenting one to two layers of palisade parenchyma and four to six layers of spongy parenchyma (Figure 4G). There were sclereids of diverse sizes and formats (Figures $4 \mathrm{G}$ and $\mathrm{H}$ ), in addition to several prismatic crystals (Figures $4 \mathrm{G}$ and $\mathrm{H}$ ) and vascular bundles, which were 


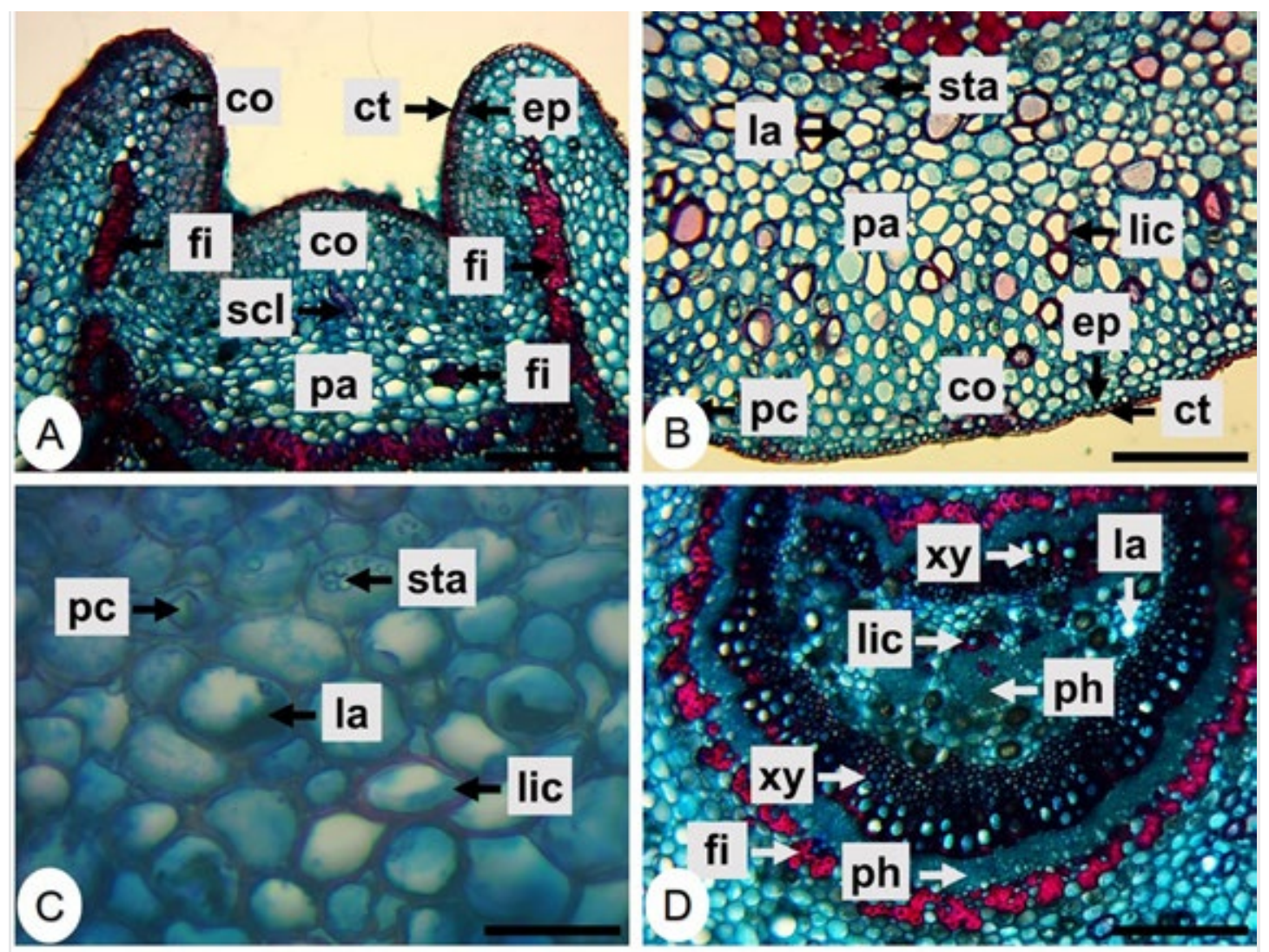

FIGURE 2 - Cross-sections of the petiole of Manilkara zapota (L.) P.Royen (Sapotaceae). A, B, C: general organization of the structures. D: detail of the cortical region. Abbreviations: $c o=$ collenchyma; $\mathrm{ct}=$ cuticle; $\mathrm{ep}=$ epidermis; $\mathrm{fi}=$ fiber; la = laticifer; lic $=$ lignified cell; $\mathrm{pa}=$ parenchyma; $\mathrm{pc}=$ prismatic $\mathrm{crystal} ; \mathrm{ph}=\mathrm{phloem} ; \mathrm{scl}=$ sclereid; $\mathrm{sta}=\mathrm{starch} ; \mathrm{xy}=\mathrm{xylem} . \mathrm{Bars}: \mathrm{A}, \mathrm{B}$, $\mathrm{D}=200 \mu \mathrm{m} ; \mathrm{C}=50 \mu \mathrm{m}$.
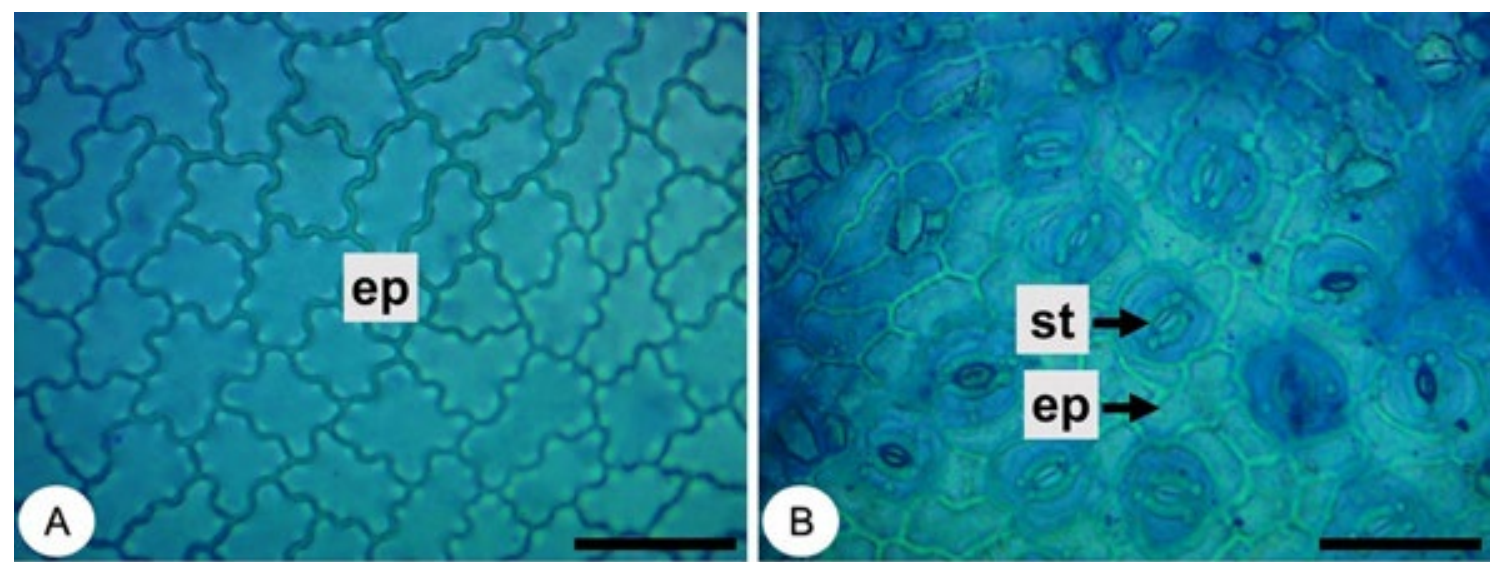

FIGURE 3 - Frontal view of the leaf blade of Manilkara zapota (L.) P.Royen (Sapotaceae). A: Adaxial surface. B: Abaxial surface. Abbreviations: $\mathrm{ep}=$ epidermis; $\mathrm{st}=$ stomata. Bars: $\mathrm{A}, \mathrm{B}=50 \mu \mathrm{m}$.

surrounded by sclerenchymatic fibers (Figure 4G).

In the cross-sections of the fruit, it was observed to be coated by a periderm (Figure 5A). The mesocarp consisted of parenchyma, and laticifers, groups of large stone cells (Figure 5A), vascular bundles (Figure 5B) and idioblasts containing raphides were visualized (Figure 5C).
Figures $6 \mathrm{~A}$ and $6 \mathrm{~B}$ correspond to the controls. The Figure 6A shows the central region of the midrib, and the Figure 6B shows the mesophyll. The phenolic compounds were identified by the presence of red coloring in the adaxial subepidermal layer and in the palisade parenchyma (Figure 6C).

Tannins were also seen in the adaxial subepidermal 

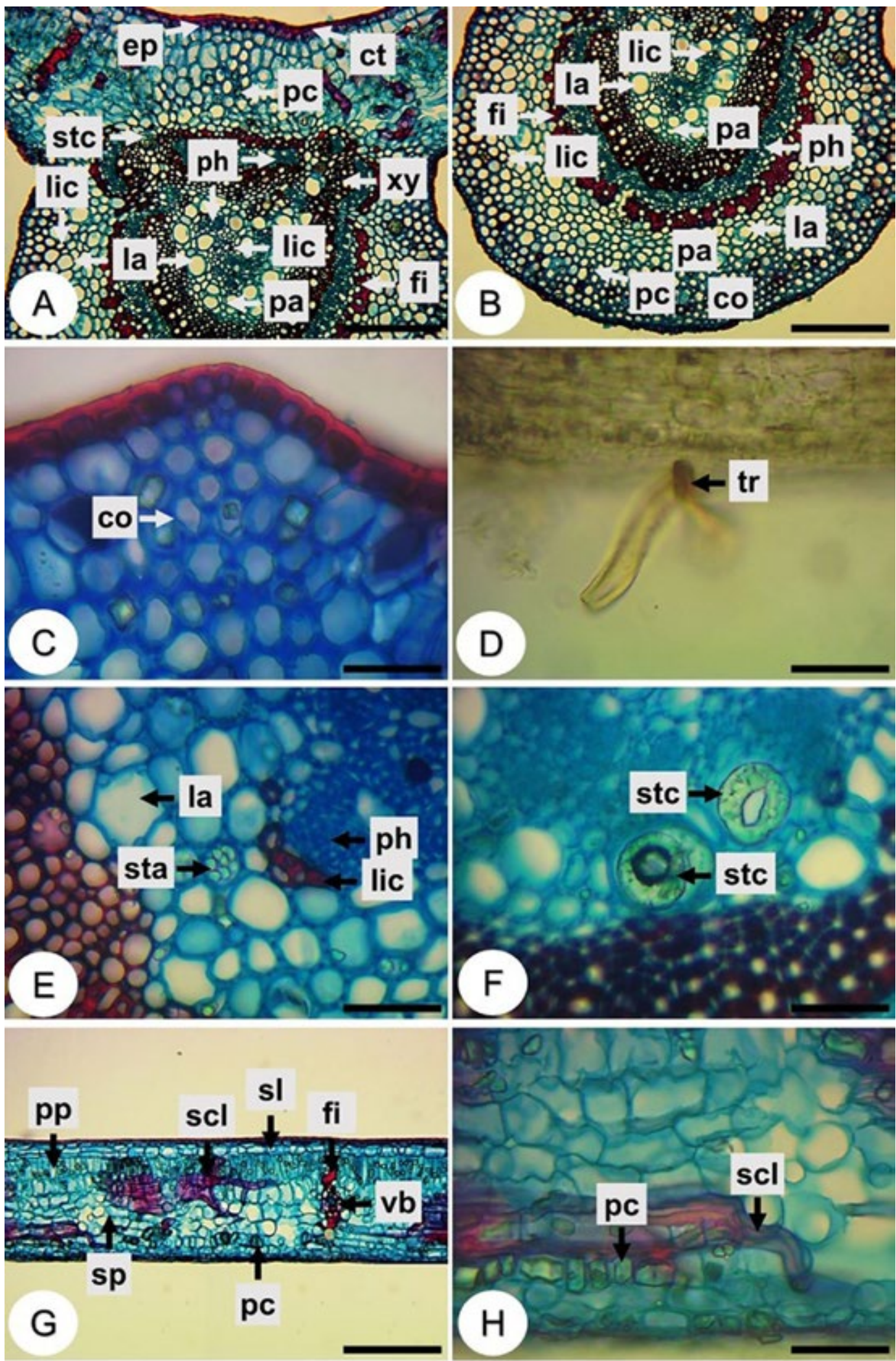

FIGURE 4 - Cross-sections of the leaf blade of Manilkara zapota (L.) P.Royen (Sapotaceae). A, B, C, E, F: midrib. D, G, H: mesophyll. Abbreviations: $\mathrm{co}=$ collenchyma; $\mathrm{ct}=$ cuticle; $\mathrm{ep}=$ epidermis; $\mathrm{fi}=$ fiber; la = laticifer; lic $=$ lignified cell; $\mathrm{pa}=$ parenchyma; $\mathrm{pc}=$ prismatic crystal; $\mathrm{ph}=$ phloem; $\mathrm{pp}=$ palisade parenchyma $\mathrm{scl}=$ sclereid $; \mathrm{sl}=$ subepidermal layer; $\mathrm{sp}=\mathrm{spongy}$ parenchyma; sta $=$ starch; stc $=$ stone cell; $\operatorname{tr}=$ trichome; $\mathrm{vb}=$ vascular bundle; $\mathrm{xy}=$ xylem. Bars: $\mathrm{A}, \mathrm{B}, \mathrm{G}=200 \mu \mathrm{m} ; \mathrm{C}, \mathrm{D}, \mathrm{E}, \mathrm{F}$, $\mathrm{H}=50 \mu \mathrm{m}$. 

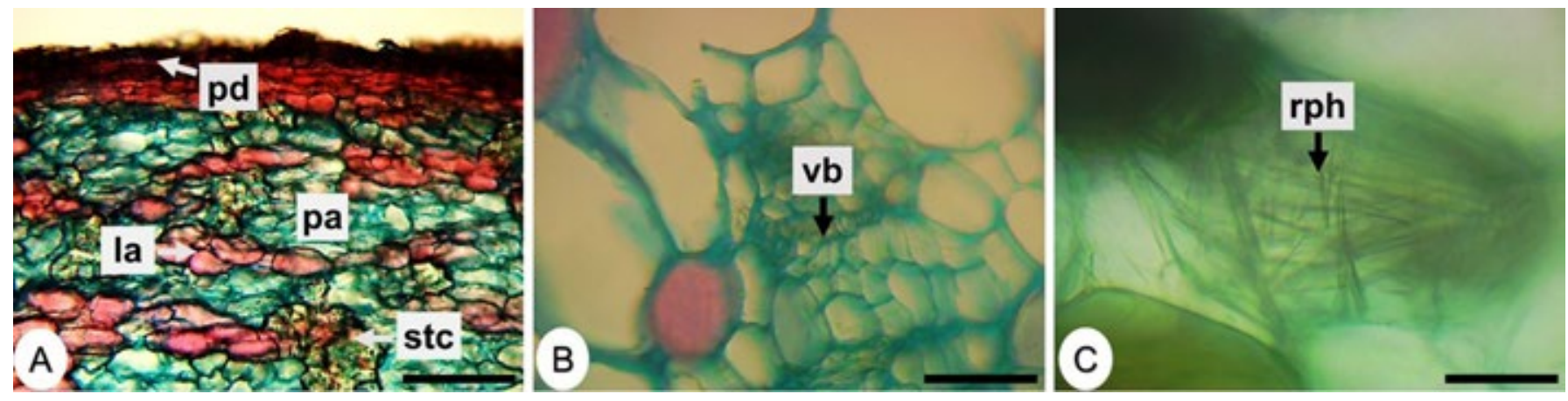

FIGURE 5 - Cross-sections of the fruit of Manilkara zapota (L.) P.Royen (Sapotaceae). A, B: general organization of the structures. $\mathrm{C}$ : detail of raphides. Abbreviations: la = laticifer; $\mathrm{pa}=$ parenchyma; $\mathrm{pd}=$ periderm; $\mathrm{rph}=\mathrm{raphide} ; \mathrm{stc}=\mathrm{stone} \mathrm{cell}$; $\mathrm{vb}=\mathrm{vascular}$ bundle. Bars: $\mathrm{A}=200 \mu \mathrm{m} ; \mathrm{B}, \mathrm{C}=20 \mu \mathrm{m}$.

layer, as well as in the palisade and spongy parenchyma (Figure 6D). Triterpenes and steroids were visualized in the epidermal cells (Figure 6E).

Lipophilic compounds were observed in cell inclusions and in the cuticle that covered the epidermis (Figure 6F). In the midrib, the presence of starch grains was revealed in the parenchymatic cells (Figure 6G); lignin in the xylem, in the lignified cells and in the sclerenchymatic fibers (Figure $6 \mathrm{H}$ ). The test to establish the nature of the crystals demonstrated their dissolution, confirming that they consisted of calcium oxalate (Figures $6 \mathrm{I}$ and $\mathrm{J}$ ).

\section{DISCUSSION}

The presence of laticifers was the main diagnostic characteristic of the Sapotaceae family (Monteiro, Andreata, Neves, 2007). According to Solereder (1908), in Sapotaceae they are of the articulated type and may be situated in all organs of the plant. In M. zapota, they are found in all analyzed parts. In the stem and petiole, laticifers are present in the cortex and in the medullar region. In the stem of Sideroxylon obtusifolium (Roem. \& Schult.) T.D. Penn. and Synsepalum dulcificum (Schumach. \& Thonn.) Daniell, they were found only in the cortex (Ayensu, 1972; Silva, 2008).

In the case of the petiole, in Pouteria grandiflora (A.DC.) Baehni (Palazzo, Monteiro, 2010) and in another 13 species of Manilkara studied by Almeida Jr. et al. (2013), laticifers were also verified in the cortex and medulla, while in Sideroxylon obtusifolium they were present only in the cortex (Silva, 2008). In the leaf blade of $M$. zapota the laticifers occurred only in the midrib, a characteristic also described by Almeida Jr. et al. (2013) for other species of Manilkara. However, the presence of laticifers in the mesophyll in Sapotaceae has also been reported in the literature, as in Synsepalum dulcificum,
Pouteria bangii (Rusby) T.D. Penn., P. caimito (Ruiz \& Pav.) Radlk., P. gardneriana (A.DC.) Radlk., $P$. grandiflora, P. procera (Mart.) T.D. Penn., P. salicifolia (Spreng.) Radlk. and P. venosa T.D. Penn. (Ayensu, 1972; Monteiro, Neves, Andreata, 2007).

Other structures characteristic of the Sapotaceae family are the trichomes (Solereder, 1908; Monteiro, Andreata, Neves, 2007). According to Metcalfe, Chalk (1950) they are commonly unicellular, 2-armed, but one of the arms is sometimes reduced or absent. In the present study, these trichomes were only visualized in the leaf blade of M. zapota. However, there have also been reports of trichomes in the stem, petiole and leaf blade of Sideroxylon obtusifolium (Silva, 2008), in the petiole and leaf blade of Synsepalum dulcificum (Ayensu, 1972) and species of Pouteria (Monteiro, Neves, Andreata, 2007), and in petioles of species of Manilkara (Almeida Jr. et al., 2013).

The occurrence of trichomes in the leaf blade of $M$. zapota is divergent in the literature. Jorge et al. (2005) reported the absence of trichomes, while Nagani, Kaneria, Chanda (2012) described the presence of unicellular trichomes. In this study, as was also found by Nagani, Kaneria, Chanda (2012), unicellular trichomes were visualized, however, it is worth noting that it was difficult to observe them in the slides after the discoloration procedure with sodium hypochlorite and staining with safranin and Astra blue. It was only possible to obtain images of the trichomes in cross-sections of fresh leaves that were not submitted to the previously mentioned methods.

With respect to the crystals, two types were identified in the studied organs of M. zapota: prismatic crystals were present in stem, petiole and leaf blade, while raphides were present in the fruits. According to Metcalfe, Chalk (1950), in Sapotaceae, the crystals may occur in solitary, clustered, or in crystal-sand form. Almeida Jr. et al. (2013) 

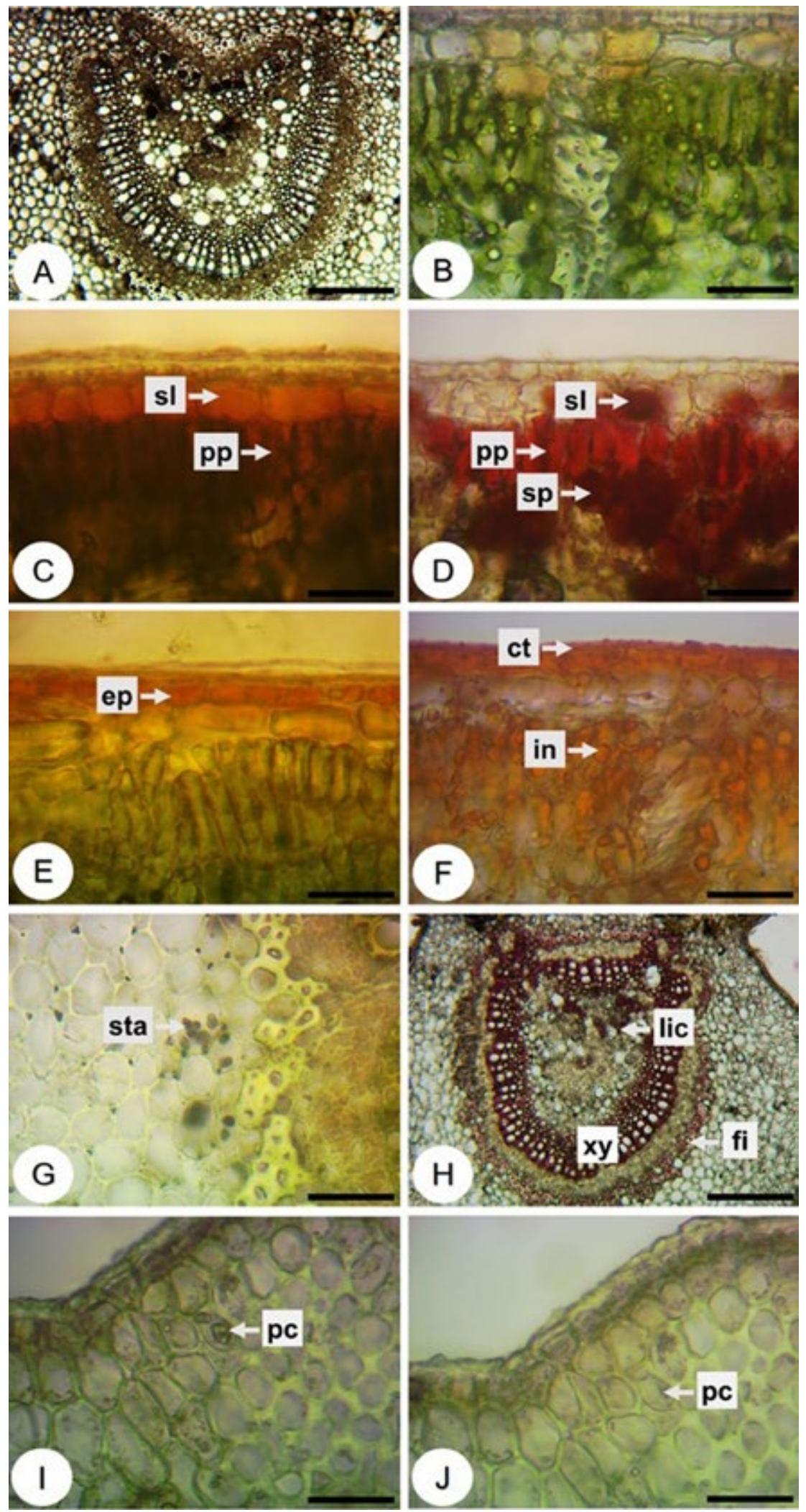

FIGURE 6 - Cross-sections of the leaf blade of Manilkara zapota (L.) P.Royen (Sapotaceae) - histochemistry. A: midrib. B: mesophyll. C: potassium dichromate (10\%). D: vanillin hydrochloric acid. E: antimony trichloride. F: Sudan III. G: Lugol's iodine reagent. H: phloroglucinol. I, J: hydrochloric acid (10\%). Abbreviations: $\mathrm{ct}=$ cuticle; ep = epidermis; $\mathrm{fi}=$ fiber; in = inclusion; lic $=$ lignified cell $; \mathrm{pc}=$ prismatic crystal; $\mathrm{pp}=$ palisade parenchyma; $\mathrm{sl}=$ subepidermal layer; $\mathrm{sp}=$ spongy parenchyma; $\mathrm{sta}=\mathrm{starch} ;$ $\mathrm{xy}=$ xylem. Bars: A, H=200 $\mu \mathrm{m} ; \mathrm{B}, \mathrm{C}, \mathrm{D}, \mathrm{E}, \mathrm{F}, \mathrm{G}, \mathrm{I}, \mathrm{J}=50 \mu \mathrm{m}$. 
cited that the presence of prismatic crystals in the petiole and leaf blade was a character for differentiation of the species of Manilkara, since, of the 13 species studied, only 4 showed prismatic crystals. Silva (2008) reported druses in the petiole of Sideroxylon obtusifolium. Relative to the location of the crystals, in the stem and petiole of $M$. zapota, they appeared only in the cortex, while in the stem of Synsepalum dulcificum and species of Madhuca, Pouteria and Sideroxylon they occurred in the cortex and medulla (Metcalfe, Chalk, 1950; Ayensu, 1972).

In the stem of species of Sapotaceae, the secondary phloem usually contained fibers (Metcalfe, Chalk, 1950), as found in this study of M. zapota, and by Ayensu (1972) and Silva (2008) for Synsepalum dulcificum and Sideroxylon obtusifolium, respectively.

Almeida Jr. et al. (2013) demonstrated that in common, the petioles of species of Manilkara presented a thick cuticle, uniseriate epidermis, sclerenchymatic fibers surrounding the vascular bundle and laticifers present in the cortical and medullary regions. In contrast, the shape of the petiole and the petiole vascular bundle conformation were characteristics that presented variations among the species of Manilkara. The presence of a nucleus of phloem in the medullary region was also described in Pouteria grandiflora by Palazzo, Monteiro (2010).

Anomocytic stomata, thick cuticle and dorsiventral mesophyll are common features in the leaf blades of species of Manilkara (Metcalfe, Chalk, 1950; Almeida Jr. et al., 2013). With respect to the adaxial surface of the leaf blade, some species of the genus have only one epidermal layer, while others may be biseriated, as in the case of Manilkara zapota, M. salzmannii (A. DC.) H.J. Lam, M. dardanoi Ducke and M. rufula (Miq.) H.J. Lam (Almeida Jr. et al., 2013). Metcalfe, Chalk (1950) described this subepidermal stratum as a hypodermis.

According to Monteiro, Neves, Andreata (2007), the occurrence of biseriated palisade parenchyma associated with the presence of a subepidermal layer and thick cuticle refers to species with xeromorphic characteristics. This may be related to the fact that the species of the genus Manilkara are distributed in different types of vegetation, with greater representativeness in areas of the Atlantic Forest and "restinga" (Almeida Jr., 2010).

Esau (1997) stated that some fruits developed suber from a phellogen of subepidermal origin and this phenomenon always occurred in some species; while in other species, this depended on the environmental conditions. Considering that the development of phellogen in the coating of fruits is rare (Jorge et al., 2005), the presence of the periderm in the fruit of M. zapota makes it an important diagnostic element.
Few histochemical studies with leaves of Sapotaceae species were found in the literature. Silva (2008) also observed the presence of lignin in the xylem and in sclerenchymatic fibers; tannins in the palisade and spongy parenchyma, and lipophilic compounds in the cuticle of the leaf blade of Sideroxylon obtusifolium. However, the cited authors did not identify starch grains and demonstrated the presence of phenolic compounds in both parenchyma and in the phloem, differing from the data found here for M. zapota.

Some phenolic compounds and terpenes have previously been isolated and identified from leaves of $M$. zapota cultivated in Egypt. Extracts from these leaves exhibited antihyperglycemic, hypocholesterolemic and antioxidant activities (Fayek et al., 2012).

\section{CONCLUSION}

Through the microscopic analysis, common characteristics were observed in the Sapotaceae; and anatomical characters useful in the diagnosis of M. zapota were found, such as the occurrence of laticifers in the cortex and in the medullary region of stem and petiole; presence of prismatic crystals in the stem, petiole and leaf blade, and raphides in fruits; presence of unicellular trichomes and subepidermal layer in the leaf blade, and periderm in the fruit. The histochemical study showed the location of phenolic compounds, tannins, triterpenes, steroids, lipophilic compounds, starch grains, lignin and calcium oxalate crystals in the leaf blade. The information found here helped with the pharmacobotanical standardization of the species studied.

\section{ACKNOWLEDGMENT}

The authors are grateful to "Conselho Nacional de Desenvolvimento Científico e Tecnológico" (409452/016-5).

\section{REFERENCES}

Ahmed R, Ifzal SM, Zaidi ZH. Studies on Achras zapota L. Part II. The chemical constituents of the leaves of Achras zapota. J Chem Soc Pak. 1982;4(3-4):171-3.

Almeida Jr EB. Diversidade de Manilkara Adans. (Sapotaceae) para o Nordeste do Brasil. [Doctoral thesis]. Recife: Universidade Federal Rural de Pernambuco; 2010. 
Almeida Jr EB, Araújo JS, Santos Filho FS, Zickel CS. Leaf morphology and anatomy of Manilkara Adans. (Sapotaceae) from northeastern Brazil. Plant Syst Evol. 2013;299(1):1-9.

Alves Araújo A, Alves M. Checklist of Sapotaceae in Northeastern Brazil. Check List. 2013;9(1):59-62.

APG IV; Chase MW, Christenhusz MJM, Fay MF, Byng JW, Judd WS, et al. An update of the Angiosperm Phylogeny Group classification for the orders and families of flowering plants: APG IV. Bot J Linn Soc. 2016;181(1):1-20.

Bukatsch F. Bemerkungen zur Doppelfärbung AstrablauSafranin. Mikrokosmos 1972;61(8):255.

Flora do Brasil 2020 - Algas, Fungos e Plantas. Sapotaceae. Rio de Janeiro: Jardim Botânico; s.d. [cited 2017 Apr 15]. Available from: http://floradobrasil.jbrj.gov.br/reflora/floradobrasil/ FB217.

Carvalho Filho MA, Cavalcanti ESB, Souza Filho ACF, Menezes JESA, Sousa AF, Costa SMO. Análise fitoquímica e avaliação das atividades antiacetilcolinesterase, antioxidante e toxicidade frente Artemia salina do extrato etanólico da casca do caule de Manilkara zapota (sapoti). 2012. [citad 2017 Apr 15]. Available from: http://www.abq.org.br/cbq/2012/ trabalhos/7/808-14241.html.

Ayensu ES. Morphology and anatomy of Synsepalum dulcificum (Sapotaceae). Bot J Linn Soc. 1972;65(2):179-87.

Esau K. Anatomia das plantas com sementes. 13.ed. São Paulo: Edgard Blücher; 1997. 293 p.

Fayek NM, Monem AR, Mossa MY, Meselhy MR, Shazly AH. Chemical and biological study of Manilkara zapota (L.) Van Royen leaves (Sapotaceae) cultivated in Egypt. Pharmacogn Res. 2012;4(2):85-91.

Gabe M. Techniques histologiques. Paris: Masson; 1968. 113p.

Ganguly A, Mahmud ZA, Uddin MMN, Rahman SMA. Invivo anti-inflammatory and anti-pyretic activities of Manilkara zapota leaves in albino Wistar rats. Asian Pac J Trop Dis. 2013;3(4):301-7.

Govaerts R, Frodin DG, Pennington TD. World checklist and bibliography of Sapotaceae. Kew: Royal Botanic Gardens; 2001.361 p.
Hossain H, Jahan F, Howlader SI, Dey SK, Hira A, Ahmed A, et al. Evaluation of anti-inflammatory activity and total flavonoids content of Manilkara zapota (L.) Bark. Int J Pharm Phytopharm Res. 2012;2(1):35-9.

Islam MR, Parvin MS, Banu MR, Jahan N, Das N, Islam M.E. Antibacterial and phytochemical screening of ethanol extracts of Manilkara zapota leaves and bark. Int J Pharma Sci. 2013;3:394-7.

Jensen WA. Botanical histochemistry, principles and practice. San Francisco: W. H. Freeman; 1962. 408p.

Johansen DA. Plant microtechnique. New York: McGraw-Hill Book; 1940. 523p.

Jorge LIF, Silva AM, Gonzalez E, Alonso ACB. Averrhoa carambola L. (Oxalidaceae) e Achras sapota L. (Sapotaceae): elementos morfo-anatômicos de orientação diagnóstica. Rev Bras Farmacogn. 2005;86(3):104-8.

Kaneria M, Chanda S. Evaluation of antioxidant and antimicrobial properties of Manilkara zapota L. (chiku) leaves by sequential soxhlet extraction method. Asian Pac J Trop Biomed. 2012;2(3):S1526-33.

Khalek MA, Khatun Z, Habib MR, Karim MR. Antitumor activity of Manilkara zapota (L.) fruits against Ehrlich ascites carcinoma in mice. Biologija. 2015;61(3/4):145-52.

Kraus JE, Arduin M. Manual básico em métodos de morfologia vegetal. Rio de Janeiro: EDUR; 1997. 198p.

Krauter, D. Erfahrungen mit Etzolds FSA-Färbung für pflanzenschnitte. Mikrokosmos. 1985;74:231-3.

Lim TK. Edible medicinal and non-medicinal plants: volume 6, fruits. New York: Springer; 2013. 606p.

Lorenzi H, Lacerda MTC, Bacher LB. Frutas no Brasil: nativas e exóticas (de consumo in natura). São Paulo: Instituto Plantarum de Estudos da Flora; 2015. 768 p.

Mace ME, Bell AA, Stipanovic RD. Histochemistry and isolation of gossypol and related terapenoids in root of cotton seedling. Phytophatology. 1974;64:1297-302.

Mace ME, Howeel CR. Histochemistry and identification of condensed tannin precurso in roots of cotton seedling. Can J Bot. 1974;52(11):2423-6. 
Manirujjaman, Sultana F, Chowdhury MAR, Shimu MC, Hossain MT, Imran-U1-Haque M. In vivo assay of antidiarrhoeal activity of methanolic and petroleum ether extracts of Manilkara zapota leaves. Int J Drug Dev Res. 2013;5(4):164-71.

Manirujjaman, Sultana F, Chowdhury MAR, Hossain MT, Imran-Ul-Haque M. In vivo assay of analgesic activity of methanolic and petroleum ether extracts of Manilkara zapota leaves. Br J Pharm Res. 2014;4(2):186-91.

Metcalfe CR, Chalk KL. Anatomy of the dicotyledons: leaves, stem, and wood in relation to taxonomy with notes on economic uses. Oxford: Clarendon; 1950.

Milind P, Preeti. Chickoo: a wonderful gift from nature. Int J Res Ayurveda Pharm. 2015;6(4):544-50.

Miranda MRA, Silva FS, Alves RE, Filgueiras HAC, Araújo NCC. Armazenamento de dois tipos de sapoti sob condição de ambiente. Rev Bras Frutic. 2002;24(3):644-6.

Monteiro MHDA, Andreata RHP, Neves LJ. Estruturas secretoras em Sapotaceae. São Leopoldo: Instituto Anchietano de Pesquisas, 2007. p.253-62. (Pesquisas, série Botânica; 58).

Monteiro MHDA, Neves LJ, Andreata RHP. Taxonomia e anatomia das espécies de Pouteria Aublet (Sapotaceae) do estado do Rio de Janeiro, Brasil. São Leopoldo: Instituto Anchietano de Pesquisas, 2007. p.7-118. (Pesquisas, série Botânica; 58).

Nagani K, Kaneria M, Chanda S. Pharmacognostic studies on the leaves of Manilkara zapota L. (Sapotaceae). Pharmacogn J. 2012;4:38-41.

Palazzo FMA, Monteiro MHDA. Morfologia de Bapeba (Pouteria grandiflora (A.DC.) Baehni, Sapotaceae). Iniciação Científica-Cesumar. 2010;12(2):121-30.
Paul SR, Hakim ML. In vivo hypoglycemic study of Manilkara zapota leaf and seed extracts. Bangladesh J Pharmacol. 2015;10(1):246-50.

Pennington TD. The genera of Sapotaceae. Kew: Royal Botanic Gardens; 1991.

Priya P, Shoba FG, Parimala M, Sathya J. Antioxidant and antibacterial properties of Manilkara zapota (L.) Royen flower. Int J Pharm Clin Res. 2014;6(2):174-8.

Sass JE. Botanical microtechnique. $2^{\text {nd }} . e d$. Ames: Iowa State College Press; 1951. 391p.

Selvaraj Y, Pal DK. Changes in the chemical composition and enzyme activity of two sapodilla (Manilkara zapota) cultivars during development and ripening. J Hortic Sci. 1984;59(2):27581 .

Silva MD. Estudo farmacobotânico de três espécies medicinais da Caatinga em Pernambuco. [Master's dissertation]. Recife: Universidade Federal Rural de Pernambuco; 2008.

Silva Jr. JFD, Bezerra JEF, Lederman IE, Moura RJM. O Sapotizeiro no Brasil. Rev Bras Frutic. 2014;36(1):86-99.

Singh M, Soni P, Upmanyu N, Shivhare Y. In-vitro anti-arthritic activity of Manilkara zapota Linn. Asian J Pharm Tech. 2011;1(4):123-4.

Solereder H. Systematic anatomy of dicotyledons. Oxford: Clarendon Press; 1908. 1182p.

Received for publication on $18^{\text {th }}$ April 2017 Accepted for publication on $28^{\text {th }}$ May 2018 